Pak. j. sci. ind. res. Ser. A: phys. sci. 2017 60(1) 22-28

\title{
Experimental Investigation of Performance Characteristics of Compression Ignition Engine Fuelled with Punnai Oil Methyl Ester Blended Diesel
}

\author{
Mathan Raj Vijayaragavan*, Ganapathy Subramanian, Lalgudi Ramachandran, \\ Manikandaraja Gurusamy, Rahul Kumar Tiwari and Sanat Kumar \\ Department of Mechanical Engineering, SRM University, Chennai, India
}

(received March 14, 2016; revised September 15, 2016; accepted October 18, 2016)

\begin{abstract}
Biodiesel is a renewable substitute to conventional diesel and offers cleaner performance. This paper deals with performance characteristics of four stroke, water cooled Compression Ignition $(\mathrm{CI})$ engine fuelled with four different oils: diesel, diesel-punnai oil biodiesel 10\% (B10), diesel-punnai oil biodiesel 20\% (B20) and diesel-punnai oil biodiesel 30\% (B30). The present research, experiments were conducted to study the effect of viscosity, cetane number, flash point, calorific value and density on performance characteristics of diesel, Punnai oil biodiesel and its different blends (B10, B20, B30). The experimental results of this study showed that the diesel has $2.6 \%$ and $4.6 \%$ higher brake specific fuel consumption (BSFC) as compared to B10 and B20, respectively at full load, whereas BSFC of diesel was same as B30 at higher load. Volumetric efficiency and mechanical efficiency of B10 was $1.2 \%$ and $7.5 \%$ higher as compared to diesel at full load condition. Brake Thermal Efficiency (BTE) and indicated thermal efficiency of B20 was $8.12 \%$ and $7 \%$ higher as compared to diesel at full load. From this study, it is concluded that Punnai oil biodiesel could be used as a viable alternative fuel in a single cylinder, four stroke, water cooled direct injection diesel engine.
\end{abstract}

Keywords: biodiesel, compression ignition engine, Punnai oil biodiesel, performance

\section{Introduction}

World energy demand is expected to increase due to the expanding urbanisation, better living standards and increasing population. At the same time when society is becoming increasingly aware of the declining reserves of fossil fuels beside the environmental concerns, it has become apparent that biodiesel is destined to make a substantial contribution to the future energy demands of the domestic and industrial economies. Moreover, a rapid decline in the fossil fuels has led scientists and researchers to look for new alternatives. Biodiesel is a suitable alternative for diesel and has an advantage over diesel because of its biodegradable nature, remarkable lubricity and better emission characteristics. The properties of biodiesel fuel mostly depend on the production technique and fatty acid composition of the oil. Although appropriate techniques are used in production of biodiesel, the properties of biodiesel fuel may not lie within the limits of the biodiesel standards due to the fatty acid composition of the oil (Serrano et al., 2013; Canakci and Sanli, 2008). So to conclude these challenges the most appropriate method to use the vegetable oils in

*Author for correspondence;

E-mail: mathanraj.v@ktr.srmuniv.ac.in
Compression Ignition (CI) engines is by converting it into fatty acid methyl ester by the process of trans esterification (Agarwal and Dhar, 2013).

Vegetable oils have good ignition characteristics due to long chain hydrocarbon structure, however, they acquire high viscosity, lower calorific value, higher density and higher molecular weight. These physical properties cause poor thermal efficiency, while using vegetable oil in the engine. These properties can be changed by using different methods such as trans esterification, dilution and cracking method (Singh, 2012) that can be used to reduce the viscosity of vegetable oils. Punnai oil biodiesel and its different blends (B10, B20, B30) can be used on existing Compression Ignition $(\mathrm{CI})$ engines to achieve both the energy and environmental benefits. There are different studies related to engine tests of biodiesel fuel blends. Rao et al. (2009) conducted experimental investigations on Jatropha biodiesel and its additive in a diesel engine. The results of the experiment showed that B100 had lower brake thermal efficiency mainly due to its high viscosity compared to diesel and B25 have closer performance to diesel. The brake thermal efficiency for B75 and B50 was found to be $14.5 \%$ and $24.45 \%$ higher 
than that of diesel fuel. Ozer (2014) carried out the experiment on waste cooking oil and its blends B5 and B10 in a single-cylinder, direct injection, four-stroke, natural aspirated diesel engine. It was found that $5 \%$ and $10 \%$ biodiesel fuel addition resulted in slightly increment on break specific fuel consumption (up to $4 \%$ ) and reduction on break thermal efficiency (up to $2.8 \%$ ). Agarwal (2007) conducted experiment on a single cylinder, four stroke, constant speed, water cooled, direct injection diesel engine (typically used in agricultural sector) was used for the experiments. The acquired data were analysed for various parameters such as thermal efficiency, brake specific fuel biodiesel consumption (BSFC) and were nearly equal to diesel. How (2014) carried out the experiment and the result showed that the BSFC of B20E5 and B20 is higher than baseline diesel. In overall, B20E5 showed 2.0-2.7\% higher BSFC compared to baseline diesel fuel at all engine loads. This was concluded due to the lower heating value of biodiesel and ethanol blends compared with that of baseline diesel. Masjuki et al. (2001) used preheated palm oil to run a CI engine. Better spray and atomization characteristics were obtained due to reduction in the viscosity of fuel while preheating it. Torque, brake-power, specific fuel consumption, and brake thermal efficiency were found to be comparable to those of mineral diesel. Raheman and Ghadge (2009) showed in his result that the reductions in brake specific fuel consumption together with increase brake power, brake thermal efficiency made the blend of biodiesel (B20) a suitable alternative fuel for diesel. Keeping these facts in mind, a set of engine experiments were conducted using Punnai oil biodiesel and different blends (B10, B20, B30) on an engine. Heating and transesterification were used to lower the viscosity of Punnai oil biodiesel and its different blends (B10, B20, $\mathrm{B} 30$ ) in order to eliminate various operational difficulties.

\section{Materials and Methods}

Biodiesel preparation. The production of biodiesel from Punnai oil was done by 2-step, trans esterification process. The first step acid, catalysed esterification reduces the free fatty acids (FFA) value of the oil to about $2 \%$.

The second step, alkaline catalysed trans esterification process converts the products of the first step to its mono-esters and glycerol. In acid esterification, 1000 $\mathrm{mL}$ Punnai oil is heated to about $50^{\circ} \mathrm{C} ; 250 \mathrm{~mL}$ methanol is added and stirred for a few minutes. With this mixture
$2 \%(\mathrm{v} / \mathrm{v})$ of sulphuric acid $\left(\mathrm{H}_{2} \mathrm{SO}_{4}\right)$ was also added and stirred at a constant rate with $50{ }^{\circ} \mathrm{C}$ for $1 \mathrm{~h}$. After the reaction was over, the solution was allowed to settle for $24 \mathrm{~h}$ in a separating funnel. The excess alcohol along with sulphuric acid and impurities floated at the top surface and was removed. The lower layer was separated for further processing (alkaline esterification). In alkaline catalysed esterification, the products of the first step were again heated to about $50-55^{\circ} \mathrm{C}$. With this mixture, $5 \mathrm{~g} \mathrm{KOH}$ dissolved in $250 \mathrm{~mL}$ methanol was added and stirred for $60 \mathrm{~min}$. After the reaction was over, the solution was again allowed to settle for $24 \mathrm{~h}$. The glycerin settled at the bottom and esterified Punnai oil rose to the top. This esterified Punnai oil (biodiesel) was separated and purified with warm water. After washing the final product was heated up to $60{ }^{\circ} \mathrm{C}$ for $10 \mathrm{~min}$.

Experimental setup. An experimental setup was made to evaluate the performance of the engine. The overall view of the experiment setup is shown in Fig. 1. The present paper discusses the details of the experimental setup, instruments used and software needed for the work. Figure 2 shows a representation of diesel engine testing facility used to study engine performance and

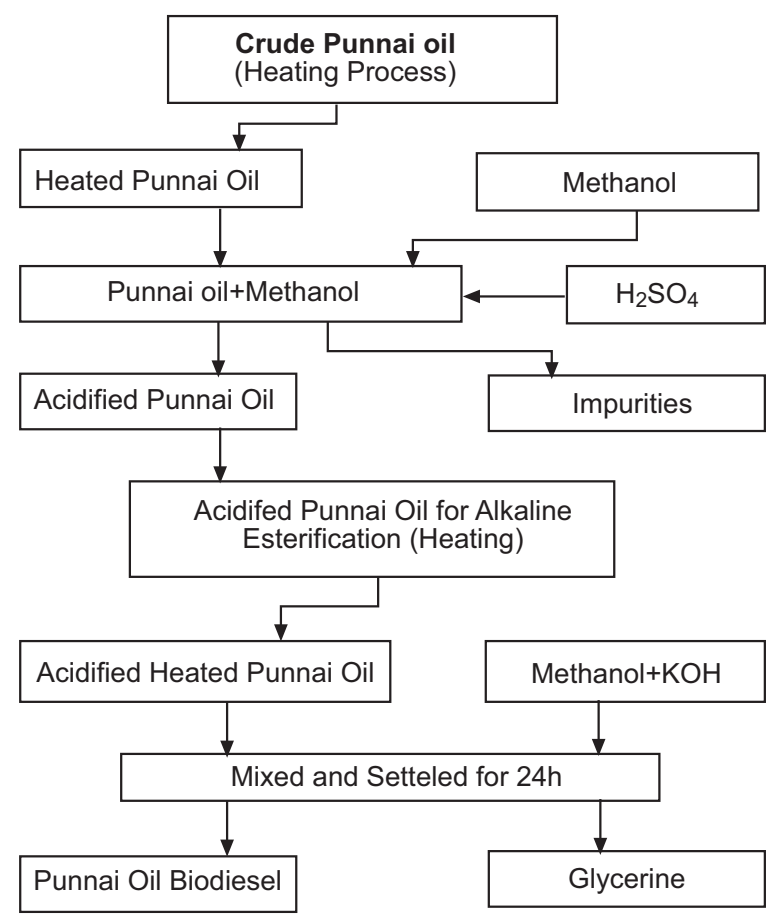

Fig. 1. Schematic representation of the 2-step transesterification. 
combustion properties. All the specifications of engine are listed in Table 1. An eddy current dynamometer was connected with the engine and used to measure engine power. To evaluate the performance parameters, the important operating parameters were engine speed, power output and fuel consumption. Significant engine performance parameters such as brake specific fuel consumption (BSFC) and brake thermal efficiency (BTE) for biodiesel and its blends were calculated.

Computerised digital data acquisition system. The values of cylinder pressure and TDC signals were taken and stored on a high speed computer based digital data acquisition system. With specially designed software

Table 1. Technical features of the test engine

\begin{tabular}{ll}
\hline \hline Engine specification & Details \\
\hline Number of cylinders & single cylinder \\
Cycle & four stroke \\
Ignition system & compression ignition \\
Bore x stroke & $87.5 \times 110 \mathrm{~mm}^{2}$ \\
Displacement volume & $661 \mathrm{~cm}^{3}$ \\
Compression ratio & $18: 1$ \\
Valve arrangement & overhead \\
Rated power & $3.5 \mathrm{kw} @ 1500 \mathrm{rpm}$ \\
Cooling medium & sater cooled \\
Eddy current dynamometer & $60 \mathrm{kw}$ \\
\hline \hline
\end{tabular}

the stored signals were processed to obtain the performance parameters (B.P, volumetric efficiency, specific fuel consumption) and also other parameters like peak pressure, maximum rate of pressure rise etc.

Optical TDC positioning sensor. An electro optical sensor was used to give a voltage pulse exactly when the TDC position was reached. This sensor consists of a well aligned pair of infrared diode and phototransistor so that the infrared rays emitted from the diode fall on the phototransistor when not interrupted. Voltage signals from the optical sensor were fed to analogue to digital converter and then to data acquisition system along with pressure signals for recording.

Load and speed measurement. The engine was coupled to an eddy current dynamometer. The specification of the eddy current dynamometer is given in Table 1 . The dynamometer unit basically comprises a rotor mounted on shaft running on bearings which rotates within a casing supported in ball bearing which forms the plate of the machine. The dynamometer load measurement is from load cell, speed measurement and a strain gauge is from a shaft mounted with a sixty tooth wheel and with magnetic pulse pickup. The voltage pulses from the sensor are sent to digital data rpm meter for pulse conversion and it displays the engine speed with an accuracy of $1 \mathrm{rev} / \mathrm{min}$.

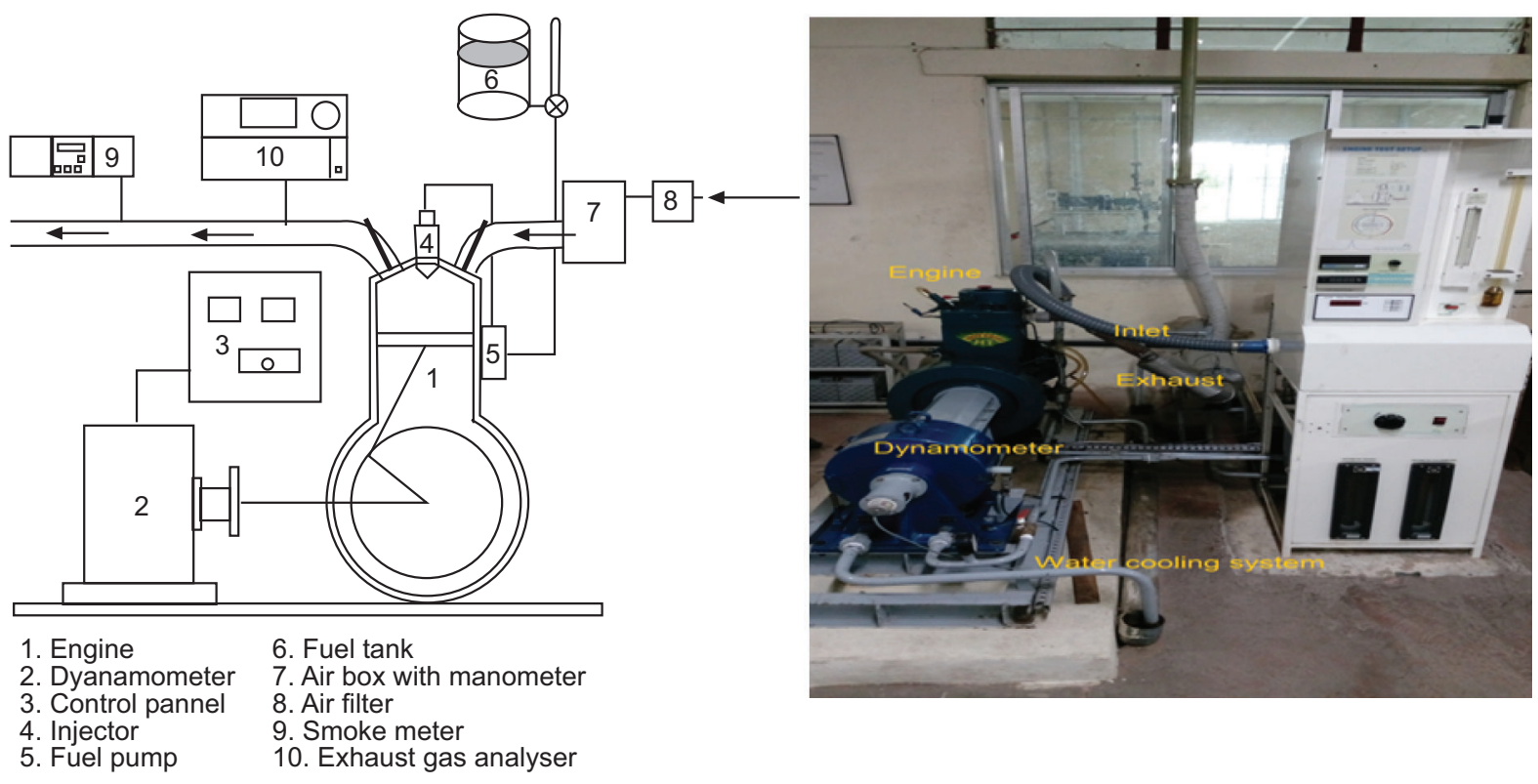

Fig. 2. Schematic diagram of the experimental step. 
Fuel properties testing. Punnai oil biodiesel and its different blends (B10, B20, B30) were prepared in lab on volume basis and its main purpose was to replace diesel fuel in maximum quantity in order to increase the amount of fuel oxygen to maximum limit, but keeping the other essential properties (calorific value, pour point, density, Cetane index, flash point and viscosity) within the acceptable limits. These essential properties of biodiesel were measured experimentally. The viscosity was measured by using a dynamic viscometer, the fuel density was measured by weighing a known volume of fuel; the measurement principle consisted of measuring the time needed for a known volume of fuel to drop from a Viscometer. All properties were measured with standard procedure given in the ASTM standards

\section{Results and Discussion}

Fuel properties. Different fuel properties of Punnai oil biodiesel (B100) and its blends (B10, B20, B30) with diesel was found and summarized in Table 2. It can be seen from this Table that the fuel properties of B10 are comparable with those of diesel. The Punnai oil biodiesel (B100), however, was found to have much higher values of fuel properties, especially viscosity and density, way above any of these standard limits - thus restricting its direct use as a fuel for diesel engines.

Density. The density of the oil is important because it gives an indication of the delay between the injection and combustion of the fuel in a diesel engine. The densities of Punnai oil biodiesel (B100) and its blend (B10, B20, B30) was observed and found to be higher than that of diesel. Thus, density of Punnai oil biodiesel (B100) was about $9.25 \%$ higher than the diesel. The densities were observed to increase with the increasing concentration of biodiesel in the blends. Reason of higher densities of Punnai oil biodiesel and its blends as compared to diesel may be due to the higher molecular weights of triglyceride molecules and free fatty acid present in them.

Kinematic viscosity. Kinematic viscosity is the most important property of biodiesel since it effects the operation of fuel injection equipment. Moreover, high viscosity may lead to formation of soot and engine deposits due to insufficient fuel atomization. The kinematic viscosity of Punnai oil biodiesel (B100) and its blends (B10, B20, B30) was found to be higher than the diesel. However, the viscosity of blends increased with increasing concentration of biodiesel in the blends.

Calorific value. The gross calorific values of B100 were found to be $38.55 \mathrm{MJ} / \mathrm{kg}$, respectively, which is $9.28 \%$ lower than $42.5 \mathrm{MJ} / \mathrm{kg}$ for diesel. This could be due to the difference in their chemical composition from that of diesel or the difference in the percentage of carbon and hydrogen content, or the presence of oxygen molecule in the molecular structure of Punnai oil and biodiesel. The calorific values of the blends proportionately decrease with the increase in biodiesel percentage.

Flash point. Flash point of the fuel is the temperature at which it will ignite when exposed to a spark or flame. Flash point varies inversely with the fuels volatility (Uriarte, 2010; Sanford et al., 2001). Flash point is the lowest temperature at which fuel emits enough vapour to ignite. The flash points of B10, B20, B30 and B100 were determined to be higher, respectively, and were not so high as compared to diesel. The flash points of all the blends were also higher than that of diesel. Thus overall flammability hazard of Punnai oil biodiesel (B100) is much less than that of conventional diesel.

Cetane number $(\mathbf{C N})$. The $\mathrm{CN}$ is a measure of the ignition quality of the fuel during combustion ignition. It provides the information about the delay time of a fuel upon injection into the combustion chamber. High CN implies short ignition delay (Raj and Sahayaraj, 2010). Fuels

Table 2. Fuel properties of Punnai oil, Punnai oil biodiesel, blends of biodiesel and diesel

\begin{tabular}{llllllll}
\hline \hline Fuel blend & Standard method & Diesel & Punnai oil & B10 & B20 & B30 & B100 \\
\hline Density $\left(\mathrm{kg} / \mathrm{m}^{3}\right)$ & ASTM D127 & 840 & 926.6 & 847.77 & 855 & 863.13 & 917.7 \\
Viscosity $(\mathrm{cST})$ & ASTM D445 & 2.87 & 12.5 & 3.11 & 3.27 & 4.23 & 5.97 \\
Flash point $\left({ }^{\circ} \mathrm{C}\right)$ & ASTM D93 & 51 & 218 & 59 & 88 & 124 & 172 \\
Cetane number & ASTM D6890 & 45 & - & 45 & 49 & 45 & 64 \\
$\mathrm{CV}(\mathrm{kJ} / \mathrm{kg})$ & ASTM D240 & 42500 & 38511 & 42150 & 40362 & 41316.2 & 38554 \\
\hline \hline
\end{tabular}


with low CN cause knocking and show increased gaseous and particulate exhaust emissions due to incomplete combustion. The $\mathrm{CN}$ were observed to increase linearly with the increasing concentration of biodiesel in the blends. This is the reason why there is less emission found in biodiesel.

Engine performance. Brake specific fuel consumption (BSFC). Brake specific fuel consumption (BSFC) is a measure of volumetric fuel consumption for any particular fuel. The variation of brake specific fuel consumption with brake power output is shown in Fig. 3. The brake specific fuel consumption is determined by dividing the total fuel consumption per hour by the power developed. As seen from the Graph 1 that B30 has almost same fuel consumption at full load condition (Puhan et al., 2005; Raheman and Phatadare, 2004). This may be due to higher viscosity and higher density of the B30 as compared to other blends of Punnai biodiesel. The study showed that the diesel has $2.6 \%$ and $4.6 \%$ higher brake specific fuel consumption (BSFC) as compared to B10 and B20, respectively, at full load.

$\mathrm{BSFC}=\mathrm{r} / \mathrm{tw}$

$\mathrm{BSFC}=$ brake specific fuel consumption

$\mathrm{r}=$ fuel consumption rate $(\mathrm{g} / \mathrm{s})$

$\mathrm{r}=$ Engine torque $(\mathrm{N}-\mathrm{m})$

$\mathrm{w}=$ Engine speed $(\mathrm{rad} / \mathrm{s})$

Total fuel consumption. The total fuel consumption is determined by measuring the volume or weight of fuel consumed by the engine under given test condition in a given time. The variation of total fuel consumption

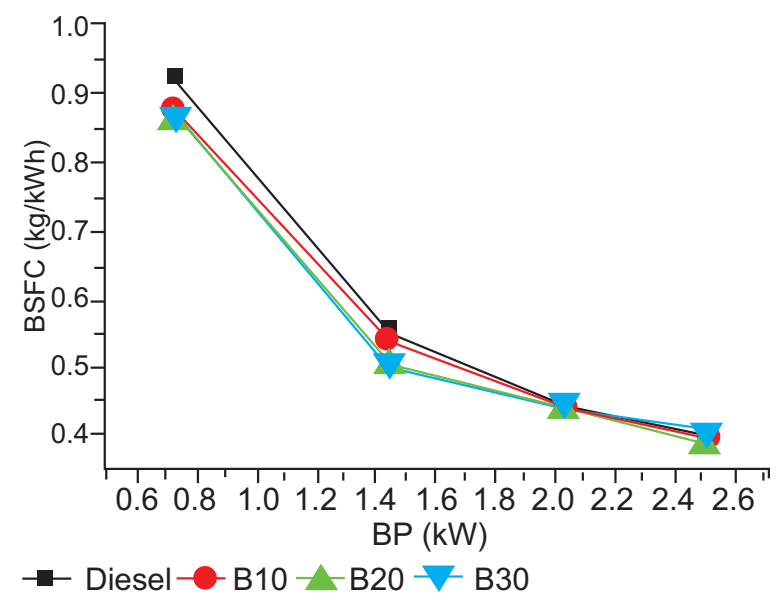

Fig. 3. Effects of biodiesel addition on brake specific fuel consumption under different engine loads. with brake power output is shown in Fig. 4. As seen from Fig. 4, B10 has the highest total fuel consumption as compared to diesel and different blends.

Brake mean effective pressure (Bmep). This is the average effective cylinder pressure that does useful work calculated from the brake power. The work accomplished during one engine cycle divided by the engine swept volume. The brake mean effective pressure is directly proportional to brake power and increases with load. As seen in Fig. 5 there is no particular change in the effective pressure of diesel and biodiesel.

Volumetric efficiency. Volumetric efficiency shows the breathing ability of the engine. More precisely, volumetric efficiency is a ratio of actual volume flow

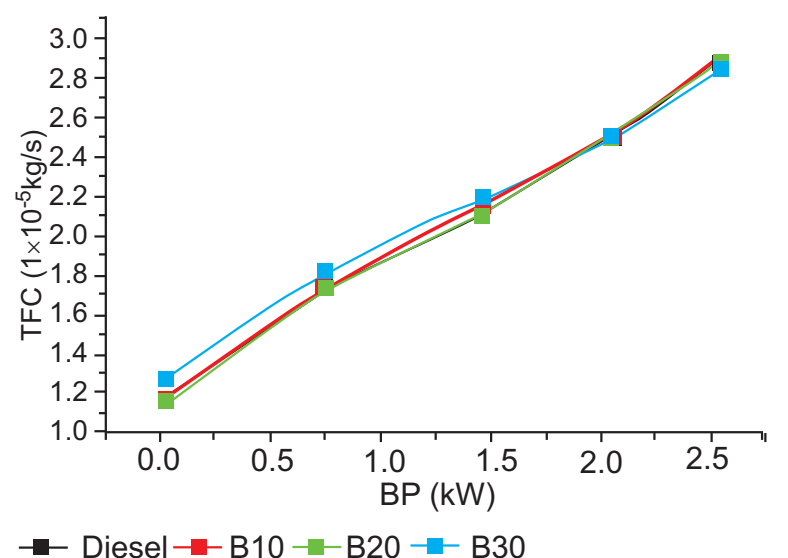

Fig. 4. Effects of biodiesel addition on total fuel consumption under different engine loads.

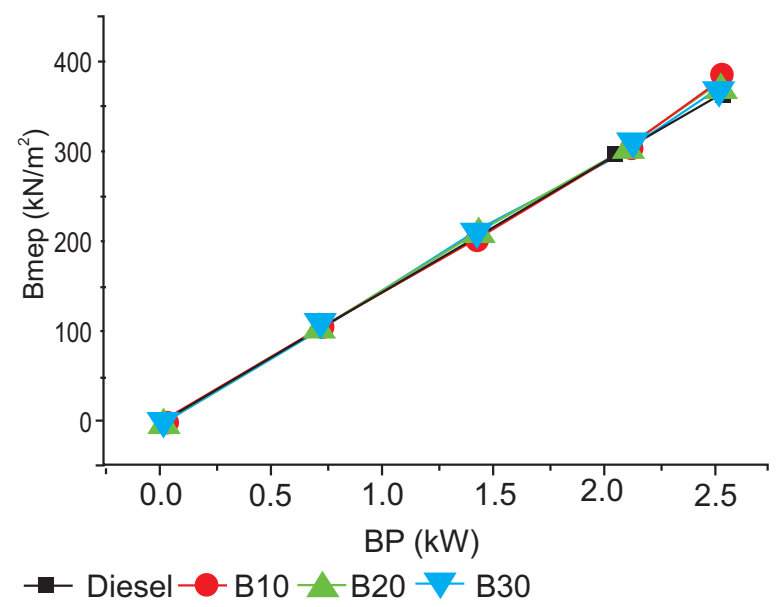

Fig. 5. Effects of biodiesel addition on brake mean effective pressure (Bmep) under different engine loads. 
rate of air into the intake system to the rate at which the volume is displaced by the system. Figure 6 shows that there are no major changes at initial load, but there is a sudden drop in efficiency of B20 at full load condition. The reason may be due to improper mixing of B20 at full load condition. Whereas the result showed that $\mathrm{B} 10$ has $1.2 \%$ higher volumetric efficiency as compared to diesel at full load.

Mechanical efficiency. Mechanical efficiency measures the effectiveness of a machine in transforming the energy and power that is input to the device into an output force and movement. Mechanical efficiency is the ratio of brake thermal efficiency to indicated thermal efficiency. The mechanical efficiency is increased with the increase of engine load due to the remarkable improve in the fuel combustion quality at high engine load as shown in Fig. 7. As seen that B10 has 7.5\% higher efficiency at full load condition as compared to diesel. The reason may be due to proper atomization of B10 and proper combustion at full load condition.

Brake thermal efficiency. The brake thermal efficiency is increased with the increase of engine load due to the remarkable improvement in the fuel combustion quality at high engine load as shown in Fig. 8. Increased brake thermal efficiency of Punnai oil biodiesel and its blends is attributed to increase in oxygen content of the fuel, resulting in improved combustion. The result showed that B20 was $8.12 \%$ higher than diesel at full load condition. Previous research works also shows that high kinematic viscosity and density fuels with lower calorific value tend to increase the brake specific fuel

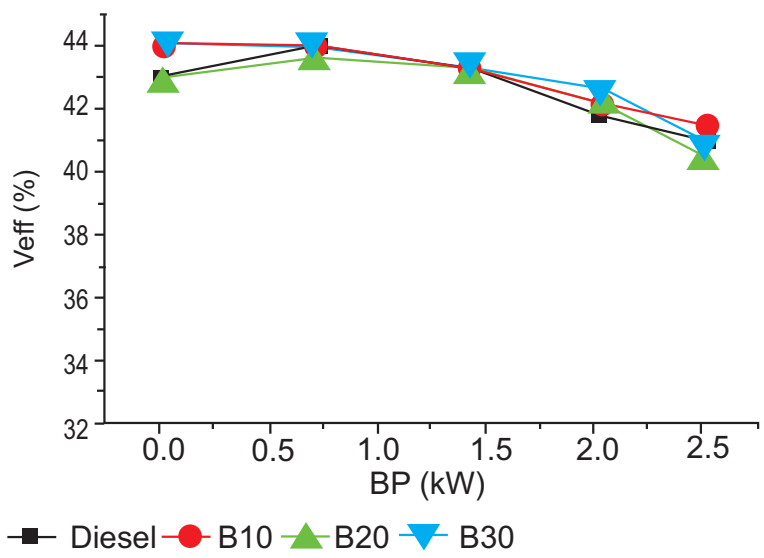

Fig. 6. Effects of biodiesel addition on volumetric fuel consumption (Veff) under different engine loads. consumption and lower the brake power as it results in poor atomisation of fuel during spraying of fuels inside the combustion cylinder (Spataru and Romig, 1995; Wagner et al., 1984).

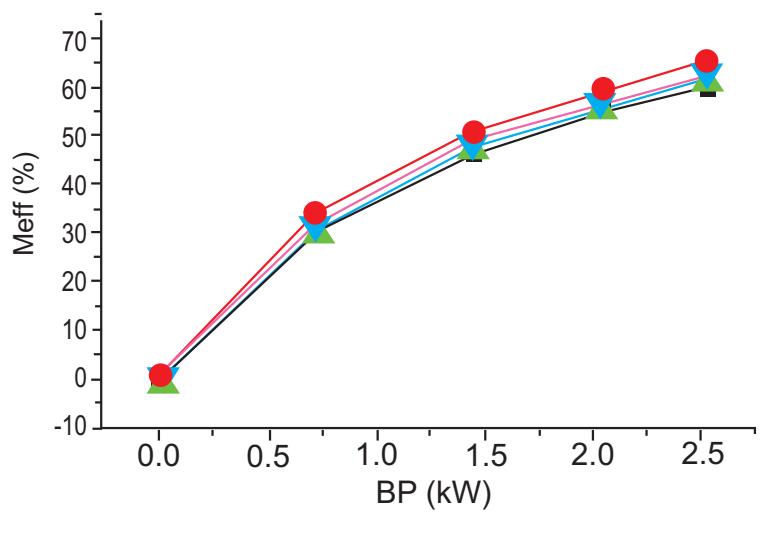

Diesel-O-B10 - $-\mathrm{B} 20-\mathrm{B} 30$

Fig. 7. Effects of biodiesel addition on mechanical efficiency under different engine loads.

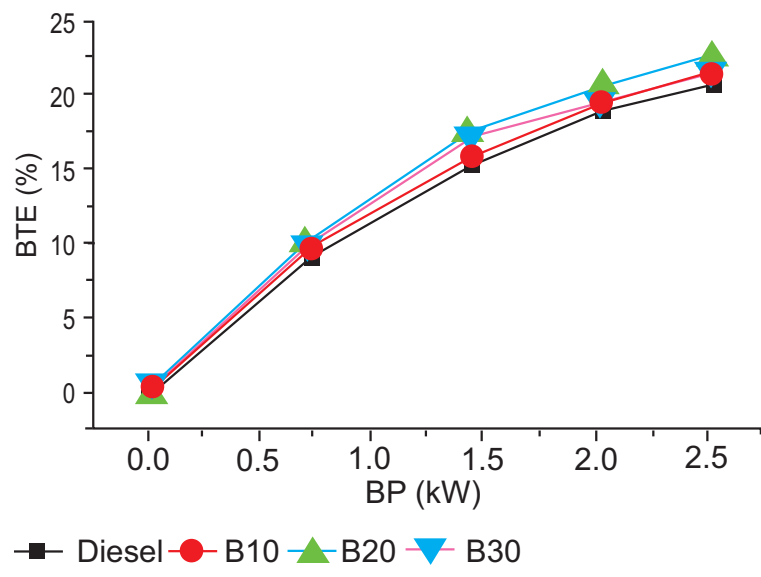

Fig. 8. Effects of biodiesel addition on brake termal efficiency under different engine loads.

\section{Conclusion}

Based on the experimental work on a compression ignition engine fuelled with Punnai oil biodiesel and its blends the following conclusions are drawn. The brake specific fuel consumption (BSFC) is increased with the increase of Punnai oil blending ratio in the blended fuels at full load. BSFC was almost same for $\mathrm{B} 30$ and diesel where B20 was $4.55 \%$ lower than the diesel at full load. The total fuel consumption increases 
with increase in load. There are no such considerable changes in the Punnai oil biodiesel and diesel at full load condition but there is slightly greater TFC for B10. The break mean effective pressure increases with increasing load. There are no considerable changes in Punnai oil biodiesel and diesel at different load conditions. Volumetric efficiency of the Punnai oil biodiesel and its blends are same as compared to diesel at different load condition except B20 that showed 20\% sudden decrease in volumetric efficiency at full load condition due to improper mixing. Mechanical efficiency increases with increasing load. Mechanical efficiency of B10 was $7.5 \%$ higher than diesel and other blends due to proper atomisation and combustion of the fuel. Brake thermal efficiency of the fuel increases with increasing load. Brake thermal efficiency of B20 was $8.12 \%$ higher due to proper combustion at different load condition.

\section{References}

Agarwal, A.K., Dhar, A. 2013. Experimental investigations of performance, emissions and combustion characteristics of Karanja oil blends fuelled DICI engine. Renew Energy, 52: 283-291.

Agarwal, D. 2007. Performance and emissions characteristics of Jatropha oil (preheated and blends) in a direct injection compression ignition engine. Applied Thermal Engineering, 27: 2314-2323.

Canakci, M., Sanli, H. 2008. Biodiesel production from various feedstocks and their effects on the fuel properties. Journal of Industrial Microbiology \& Biotechnology, 35: 431-441.

How, H.G. 2014. Engine performance, emission and combustion characteristics of a common-rail diesel engine fuelled with bioethanol as a fuel additive in coconut oil biodiesel blends. Energy Procedia, 61: 1655-1659.

Masjuki, H.H., Kalam, M.A., Maleque, M.A., Kubo, A., Nonaka, T. 2001. Performance, emissions and wear characteristics of an I.D.I diesel engine using coconut blended oil. Journal of Automobile Engineering, 3: 393-404.

Ozer, C. 2014. Combustion characteristics, performance and exhaust emissions of a diesel engine fueled with a waste cooking oil biodiesel mixture. Energy Conversion and Management, 87: 676-686.

Puhan, S., Vedaraman, N., Ram, B.V.B., Sankarnarayanan,
G., Jeychandran, K. 2005. Mahua oil (Madhuca indica seed oil) methyl ester as biodiesel-preparation and emission characteristics. Biomass Bioenergy, 28: $83-87$.

Raheman, H., Ghadge, S.V. 2009. Performance of compression ignition engine with Mahua (Madhuca indica) biodiesel. Fuel, 86: 14-34.

Raheman, H., Phadatare, A.G. 2004. Diesel engine emissions and performance from blends of karanja methyl ester and diesel. Journal of Biomass Bioenergy, 27: 393-397.

Raj, F.R.M.S., Sahayaraj, J.W. 2010. A comparative study over alternative fuel (biodiesel) for environmental friendly emission. Chennai, India: Recent Advances in Space Technology Services and Climate Change (RSTSCC), IEEE Conference, pp. 80-86.

Rao, H.Y.V., Voleti, R.S., Sitarama, Raju, A.V., Reddy, P.N. 2009. Experimental investigations on jatropha biodiesel and additive in diesel engine. Indian Journal of Science and Technology, 2: 25.

Sanford, S.D., White, J.M., Shah, P.S., Wee, C., Valverde, M.A., Meier, G.R. 2001. Feedstock and Biodiesel Characteristics Report, Available from:/http://www. regfuel.com/pdfs/Feedstock\%20and\%20Biodiesel \%20Characteristics\%20Report.pdf

Serrano, M., Martinez, M., Aracil, J. 2013. Long term storage stability of biodiesel: influence of feedstock commercial additives and purification step. Fuel Processing Technology, 116: 135-141.

Singh, S. 2012. Study of various methods of biodiesel production and properties of biodiesel prepared from waste cotton seed oil and waste mustard oil. M.E. Thesis in Thermal Engineering, Thapar University, India.

Spataru, A., Romig, C. 1995. Emissions and engine performance from blends of soya and canola methyl esters with ARB\#2 diesel in a DCC 6V92 TA MUI engine. SAE Paper No. 952388, DIO:10.4271/ 952388.

Uriarte, F.A.J. 2010. Biofuels from Plant Oils; Available from:/http://www.asean foundation.org/documents/ books/biofuel.pdf.

Wagner, L.E., Clark, S.J., Schrock, M.D. 1984. Effects of soybean oil esters on the performance, lubricating oil and water of diesel engines. SAE Paper No. 841385, Warrendale, PA, USA. 